\title{
Modeling Fertilizer Demand in Cotton-Producing Villages of Benin: Does Price Matter in a Centralized Distribution System?
}

\author{
Barthelemy G. Honfoga, PhD \\ University of Abomey-Calavi, School of Economics, Socio-anthropology \\ and Communication for Rural Development, Benin
}

\begin{abstract}
Cotton is a strategic crop in Benin's economy and fertilizer is a crucial necessity for its development. Fertilizer supply is awkwardly cotton-oriented and depends totally on imports. Spurious liberalization, characterized by partial state withdrawal combined with a rigid distribution agreement between the state, fertilizer traders and farmers' cooperatives, led to a drastic decline in fertilizer use and cotton production. Although fertilizer consumption resumed timidly with reforms, the supply system remained centralized (importers' licensing, distribution quotas, price administration). This study inquired whether price is relevant in fertilizer demand in such a business environment. Randomly-selected 577 cotton farmers from purposively-chosen 191 cotton-producing villages, were interviewed about fertilizer use and distribution using structured questionnaires. Determinants of average villagelevel fertilizer demand, elicited using a multiple regression model with a joint agronomic and marketing perspective, included at $5 \%$ or $1 \%$ significance level: the region's dummy, share of cotton in cultivated area, rural roads' density, distance 'village store - farmer's fields, and off-farm income. Other non-negligible factors included: estimated cost price, soil degradation rate, diffusion rate of water and soil conservation techniques, proportion of leased land area and distance 'farmer's house - local agricultural market'. Despite an administered pan-territorial district-level price, fertilizer demand was still sensitive to the actual farm-gate prices. However, the business environment had a stronger influence. The policy levers to increase fertilizer use intensity include the development of road and market infrastructures, promotion of market orientation of farming and off-farm activities, wise liberalization of fertilizer retail market, and reform of the licensing system.
\end{abstract}


Keywords: Cotton, liberalization, fertilizer demand, cost price, business environment.

\section{Introduction}

Cotton is a strategic crop in Benin's economy, accounting for $70 \%$ of the total value of exports, 35\% of non-customs tax revenues and $13 \%$ of GDP (Ton and Wankpo, 2004). More than 60\% of the country's land have tropical ferruginous soils, poor in nitrogen and phosphorus (Igue et al., 2016; Agossou, 1983; Sanchez and Jama, 2002). Therefore, the use of mineral fertilizers is a crucial necessity to intensify agriculture, particularly cotton production. Government subsidies to cotton farmers amounted to 47.45 billion FCFA over the 2001/02-2008/09 period, of which 6.5 billion FCFA were granted for fertilizers alone in 2008/09 (Ahohounkpanzon and Zakari Allou, 2010). However, fertilizer use per ha of arable land decreased from $16.4 \mathrm{~kg}$ in 2002 to $4.8 \mathrm{~kg}$ in $2013^{2}$. Average seed cotton yield was less than 1 ton/ha over the 1961-2008 period (CIPB, 2007), and since then rarely it has exceeded 1.2 ton/ha, against a potential yield of 3 tons/ha.

For several decades, Benin has been importing almost $100 \%$ of its fertilizer consumption, more than $90 \%$ of which is destined for cotton. From the mid-1960s until the cotton sub-sector liberalization in 1992, the supply and distribution of fertilizers were in the hands of the State, particularly the cotton parastatal SONAPRA ${ }^{3}$. Attempts at local fertilizer production in Benin and elsewhere in West Africa and Asia did not bear fruit because they were based on the importation of expensive raw materials (FAO/IFA, 2000). Just after liberalization, inadequate taxation and the imposition of distribution quotas on licensed private importers made locally-produced fertilizers less competitive than imported fertilizers (Tomavo, 2005 ${ }^{4}$ ). As for the latter, the licensing system which prevailed during the 2000-2011 period with the Cotton Interprofessional Association (AIC) led again to the centralization of fertilizer supply, making the market less transparent, and to the lack of satisfaction of cotton farmers' needs (Honfoga, 2012). Although fertilizer consumption increased from 20,000 tons on average between 1960-1990 to about 116,000 tons in 1999 in response to the world cotton boom, it fell to 50,000 tons in 2005 and seed cotton production decreased drastically until 2008. Reform

\footnotetext{
${ }^{2}$ Source: The WorlBank -- World Development Indicators: Agricultural inputs (http://donnees.banquemondiale.org/indicateur/AG.CON.FERT.ZS?locations=BJ\&view=chart accessed ...)

${ }^{3}$ SONAPRA: "Société Nationale pour la Promotion Agricole". It is the former public structure in charge of the cotton sub-sector, including input and extension service delivery to farmers, seed cotton purchase under contract farming, cotton ginning and fiber exports. All these functions underwent a partial liberalization process since 1992, with various degrees of private sector's implication and gradual delegation of the role of the state to the Cotton Inter-professional Association (AIC).

${ }^{4}$ Personal communication on the site of Hydrochem Benin SA, 13 January 2005.
} 
programs (PARFC and PARFCB $)^{5}$ were therefore implemented by the government to boost production (Bessou, 2013).

The common feature of fertilizer procurement and distribution system overtime is that cotton farmers' individual demands for fertilizers are expressed via their village cooperatives at least 6 months before the beginning of the agricultural season. Quantities demanded are corrected by cooperatives' leaders with regard to the likely cotton areas farmers could cultivate, and grouped as village level cooperatives' demands. The latter are then submitted transmitted to the central cotton administration who estimates the national demand, prepares the call for fertilizer supply (including types of fertilizers, quantities, maximum prices, dates of delivery, and other bidding conditions) and get tenders from private importers. All this happens under the prescriptions of the licensing system designed by the administration. The complex context of the liberalization process in the fertilizer sector in Benin and the supply practice thereof, are hereafter summarized, together with recent events.

From 1992 to 1999, there was a gradual and step by step liberalization in the fertilizer sector, meaning that government still intervened where the private was absent. But, at the same time the quality of delivery service to farmers declined drastically because most extension officers were sent off as a result of the structural adjustment program. From 2000 up to 2011, the private sector (traders) in charge of fertilizer supply found out the need to supplement extension services to cotton farmers through the existing government local offices. Over both periods, the village level is totally administered by farmers' cooperatives. During the last five years (2011-2015), the government fully controlled again the agricultural input sector and local distribution was completely achieved by the former extension officers. Following the 2016 presidential elections, which were won by the former leader of the private cotton input-and-output oligopoly, AIC was restored and state extension officers were lastly fired.

Regarding the distribution practice, at the beginning of the cotton agricultural year, farmers are requested to express their needs for cotton fertilizers based on likely cotton area to be cultivated; then cooperatives' grouped orders are collected by AIC and factored in import tenders ${ }^{6}$. The supply chain is organized as follows: on the one hand, the 'district-to-villages' link remained under the control of district-level farmers' cooperative unions, under an AIC-controlled agreement for the refund of transportation and

\footnotetext{
${ }^{5}$ PARFC : «Programme d'Appui à la Réforme de la Filière Cotonnière »; PARFCB : « Programme d'Appui à la Réforme de la Filière Cotonnière au Bénin » (2 ${ }^{\text {ème }}$ phase).

${ }^{6}$ In the tenders, not all the quantity demanded by farmers is approved by AIC, by fear that subsidized fertilizers supplied on credit would be diverted to food crops or fraudulently sold outside the country, leading to difficult debt recovery.
} 
handling costs, and payment of distribution commissions by private importers to the unions. On the other hand, local distribution, i.e. the 'village-to-farms' link, which deals directly with the producers' interface, has been only spuriously liberalized and remained in the hands of village farmers' cooperatives, under the agreement that district-level cooperative unions would refund to them the said commissions for the local distribution service. The costs of fertilizer transportation to the fields are directly borne by farmers themselves. Officially, no independent retailer is allowed, by fear of products' adulteration or fraudulent sales of subsidized fertilizers outside the country, but also -in a hidden agenda- for securing commissions to cooperatives.

Overall, institutional instability in the management of the liberalized cotton sub-sector (SONAPRA 1992-1999, AIC 2000-2010, SONAPRA 20112015, AIC from 2016) negatively affected the fertilizer market in Benin. After more than 20 years of liberalization, the institutional arrangement between fertilizer traders and farmers' village cooperatives is such that cotton farmers do not deal directly with traders, but only through their apex organizations via a national parastatal intermediary. Finally, the market was reduced to a private oligopoly (Bidaux and Soulé, 2005) where perverse incentives to traders prevailed (Honfoga, 2013). Figure 1 shows the comparative trends in fertilizer consumption and cotton production, together with prices, from 1995 to $2015^{7}$. With such a supply and distribution system, cotton and village-gate fertilizer prices and input credit remained centrally administered in a hybrid, indirect and floating-responsibility contract farming with producers. The fertilizer pricing system remained state-controlled as the administered cost price structure shows (Table 1). Although relative distribution costs decreased by $9 \%$ from 2000 and 2004, average absolute fertilizer price increased by $10.2 \%$ against a $7.6 \%$ decrease from 1995 to 2000 .

Considering the veiled state control of fertilizer supply through the AIC's licensing system in Benin and knowing that farmers' demand for cotton fertilizers discretely includes that of cereals (maize, sorghum, millet) and sometimes other cash crops (cashew, vegetables), this study raises the question of whether fertilizer price still has a significant influence, as the demand theory would suggest. Indeed, with the above-mentioned frequent institutional disturbances, one may assume that price no more determines fertilizer use by cotton farmers. If this assumption is verified, this would mean that non-price factors affect more strongly fertilizer demand than price, and that private traders would not be motivated to design cost-reduction strategies to make fertilizers more accessible to cotton farmers until such factors are genuinely

\footnotetext{
${ }^{7}$ Although this paper draws on '2003-2005' primary survey data, this figure is presented for the sake of updating on the trends in the national fertilizer market until today. Official data on fertilizer imports, consumption and prices for the period 2006-2015 are not reliable enough, due to above mentioned institutional instability. Missing values were still not available.
} 
addressed. What are these factors then?

In this inquiry, it is however important to distinguish between the fertilizer selling price on credit and the distributor's cost price ${ }^{8}$, both administered by the centralized fertilizer supply system, and the estimated cost price $^{9}$ that farmers effectively bear (Honfoga, 2013). Administered prices are often pan-territorial or regional monopoly prices, with no intra-regional differences, and are therefore not appropriate for a regression analysis. The estimated cost price is used in a multiple regression model, with the aim to assess whether price actually matters among the determinants of cotton farmers' demand for fertilizers.

In the next sections, a literature review is made of pricing policies in imperfect markets after liberalization and of the theoretical background of fertilizer demand. Then the methodology of the study is described, especially the econometric modeling of fertilizer demand, followed by the presentation of study results and discussion. Suggestions for optimal fertilizer policies in Benin and elsewhere in West-African cotton-producing countries are finally formulated.

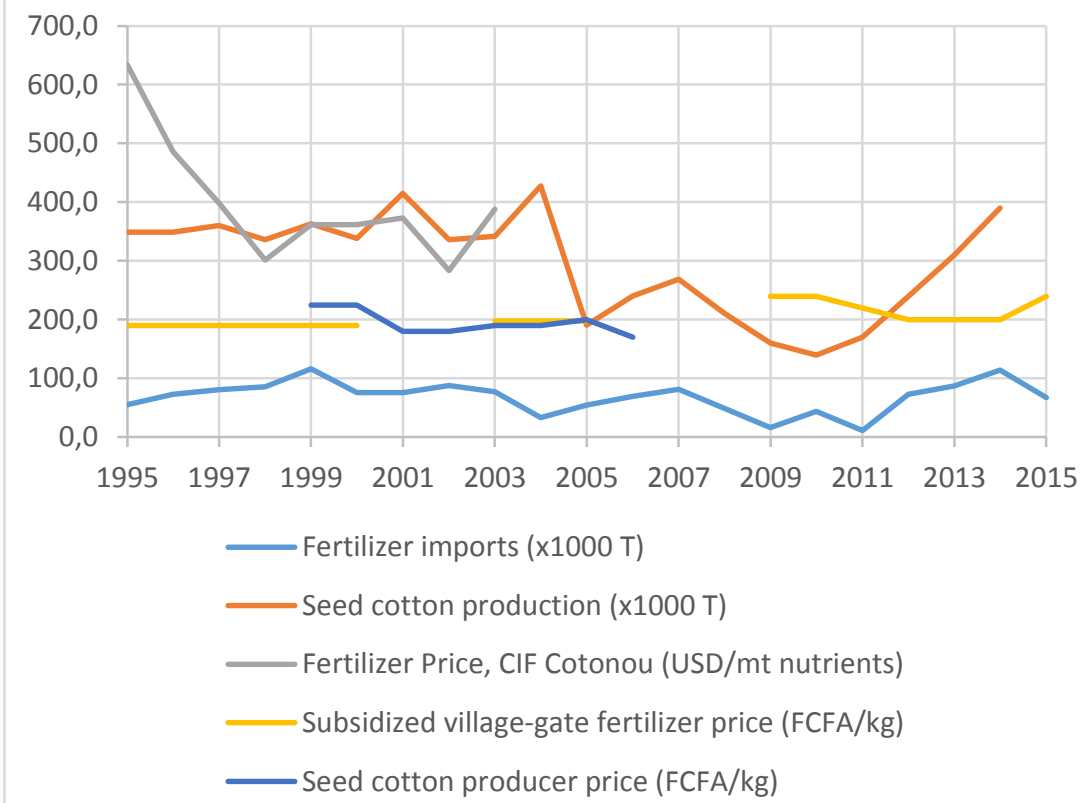

Figure 1: Comparative trends in fertilizer consumption, seed cotton production, and prices (1995-2015)

\footnotetext{
${ }^{8}$ It includes: CIF + distribution costs (transportation, transit, handling, warehousing, various taxes and other port charges, bank charges, authorized/official distributor net margin).

${ }^{9}$ Calculated using the official cost price structure and the estimated competitive transportation cost based on actual distance from port to village fertilizer store.
} 


\section{Data sources}

Fertilizer imports and Subsidized village-gate price: 1995-2003: AIC; 2005-2015: CRA-CF.

Seed cotton production: 1995-1998: Peter Ton and Eustache Wankpo (2004). La production de coton au Bénin, Projet No. 2618, Agriterra, Arnhem, Pays-Bas; 1999-2008: AIC, reported by Ahohounkpanzon and Zakary Allou (2010); 2009-2015:

http://actualites.visages-dubenin.com/2015/09/30/production-du-coton-au-benin-encore-beaucoupdefforts-a-faire/ .

Fertilizer CIF price: Calculated from FAO database as the ratios of import values of manufactured fertilizers to total fertilizers imports. Nutrients $=\mathrm{N}+\mathrm{P} 2 \mathrm{O} 5+\mathrm{K} 2 \mathrm{O}$.

Table 1: Trends in the simplified structure of average fertilizer cost price according $(1995 / 96-2004 / 05)$

\begin{tabular}{|c|c|c|c|c|c|c|c|c|}
\hline \multirow[b]{2}{*}{ Cost items } & \multicolumn{3}{|c|}{$\begin{array}{c}2004 / 200 \\
5\end{array}$} & \multicolumn{3}{|c|}{$\begin{array}{c}2000 / 200 \\
1\end{array}$} & \multicolumn{2}{|r|}{$\begin{array}{c}1995 / 199 \\
6\end{array}$} \\
\hline & $\begin{array}{c}\text { FCFA } \\
/ \mathrm{Kg}\end{array}$ & $\begin{array}{l}\text { Share } \\
(\% \text { Pc) }\end{array}$ & $\begin{array}{c}\text { Chang } \\
\text { e } \\
2000- \\
2004 \\
(\%)\end{array}$ & $\begin{array}{c}\text { FCFA } \\
/ \mathrm{Kg}\end{array}$ & $\begin{array}{l}\text { Share } \\
(\% \text { Pc) }\end{array}$ & $\begin{array}{c}\text { Chang } \\
\text { e } \\
1995- \\
2000 \\
(\%)\end{array}$ & $\begin{array}{c}\text { FCFA } \\
/ \mathrm{Kg}\end{array}$ & $\begin{array}{l}\text { Share } \\
(\% \text { Pc })\end{array}$ \\
\hline & 157.4 & & & 138.0 & & & & \\
\hline CIF price & 5 & 75.6 & 3.5 & 9 & 73.1 & 0.5 & 147.1 & 72.7 \\
\hline Transportation & 20.67 & 9.9 & -1.8 & 19.11 & 10.1 & 23.9 & 16.5 & 8.2 \\
\hline $\begin{array}{c}\text { Transit, } \\
\text { warehousing/handling, } \\
\text { maritime expertise }\end{array}$ & 6.80 & 3,3 & $-9,3$ & 6.80 & 3.6 & 18.7 & 6.20 & 3.0 \\
\hline Capital cost (Bank) & 13.07 & 6.3 & -16.7 & 14.24 & 7.5 & -26.0 & 20.83 & 10.2 \\
\hline Other costs & 8.28 & 4.0 & 11.2 & 6.76 & 3.6 & -22.4 & 9.42 & 4.6 \\
\hline $\begin{array}{l}\text { Distributor's net } \\
\text { margin* }\end{array}$ & 1.89 & 0.9 & -10.0 & 1.95 & 1.0 & -9.0 & 2.21 & 1.1 \\
\hline Total distribution cost & 50.71 & 24.4 & -9.4 & 50.81 & 26.9 & -4.1 & 57.38 & 28,1 \\
\hline Cost price at delivery & 208.1 & & & 188.9 & & & 204.4 & \\
\hline$(\mathrm{Pc})$ & 6 & 100.0 & 10.2 & 0 & 100.0 & -7.6 & 9 & 100.0 \\
\hline
\end{tabular}

Source: Calculated using data from ONS, the National Cotton Income Stabilization Board.

The distributor is the licensed importer who is also in charge of fertilizer transportation from the port to district central warehouses. The net margin here is the one set by the cotton sector administration; it is not the actual margin the distributor gets. He obtains compensation from price differences across regions and from the transportation cost he declares at the end of the delivery service. 


\section{Literature review}

\section{Pricing policies in imperfect markets after liberalization}

The main theoretical basis of liberalization policies recommended by the World Bank is the modified free market. Based on the equilibrium prices of supply and demand in perfect competition (neoclassical theory) and integrating notions of equity in the management of public goods (Stiglitz 1987), these policies recommended greater participation of the private sector and less State intervention in the production and trade of private goods. The objective was to improve the growth of African economies through more efficient use of resources and sustained efficiency in the provision of services and goods. Liberalization policies and structural adjustment programs (SAPs) implemented since the late 1980s in most West African countries have led to the redefinition of the role of the State in agricultural markets. These reforms were aimed to reduce market distortions imposed by the State, such as public monopolies in input and output marketing, barriers to entry, subsidies, etc. However, the public sector still has a role to play in the promotion of trade and economic development, through the formulation of fair regulatory frameworks and infrastructure support. Misunderstanding this, a few years after the beginning of liberalization, the State resumed its direct interventions in the market, with the justification that the objectives of equity, sustainable use of resources and the well-being of populations may not be achieved if the market is left only to the private sector (van Tilburg et al., 2000, Klein \& Hadjimichael 2003). Intense debate then followed on relevant policies thereof (price vs. nonprices subsidies, discriminatory taxes on non-essential vs. essential goods, etc.), especially in the agricultural sector where poverty rate is the highest (Druilhe et Barreiro-Hurlé, 2012; Wanzala-Mlobela et al., 2013).

It is finally agreed that liberalization in Sub-saharan Africa should pay attention to the fragile nature of African economies. While agricultural trade would be left to the private sector, the State should guarantee the provision of public goods and services (basic infrastructure and technology, information and communication facilities) in order to promote competition and stimulate private investment (van Tilburg et al., 2000; Klein and Hadjimichael, 2003). It is private sector's primary business duty to invest in private distribution infrastructure (storage facilities, means of transportation, etc.) and promotional activities to raise demand for private goods (Coughlan et al., 2001).

In the practice, fertilizer market liberalization in most French-speaking West African cotton producing countries remained partial and limited to importation companies, under subtle state control through parastatal structures such as the Inter-professional Cotton Association (AIC) and its licensing system in Benin. The context and practice of fertilizer distribution in this country was described earlier. 
Market regulation by the State has led to serious and greater input market distortions due to some government officials' resistance to liberalization, in relation with their hidden agenda (political, bureaucratic, extra income) (Dedehouanou, 2003; Wallis \& Dollery 1999; Ellis 1992). It appears then that the complex post-liberalization institutional environment in Benin was motivated by rents, against the fair sake for timely delivery of quality fertilizer at desired quantities and affordable prices. Did it deny the role of price in cotton farmers' decision to buy fertilizers? This study proposes a quantitative diagnosis of the relative importance of price and business environment factors on fertilizer demand, with the view to suggest appropriate policy measures for cost-effective fertilizer supply and sustained agricultural intensification among cotton farmers.

\section{Theoretical background of fertilizer demand}

\section{A brief overview of the microeconomic theory of demand ${ }^{10}$}

Demand theory is about the relationship between consumer demand for goods and services and their prices. Demand is the quantity of a good or service that consumers are willing and able to buy at a given price in a given time period. Based on the perceived utility of goods and services by consumers, companies adjust the supply available and the prices charged. Effective demand is when a desire to buy a product is backed up by an ability to pay for it. Latent demand exists when there is willingness to buy among people for a good or service, but where consumers lack the purchasing power to be able to afford the product ${ }^{11}$. The demand for a product $X$ might be connected to the demand for a related product $\mathrm{Y}$ - giving rise to the idea of a derived demand. Product $\mathrm{Y}$ is either a substitute or a complementary good/service.

In general, many factors affect demand. The law of demand states that, all other factors being equal (the Ceteris paribus assumption), as the price of a good or service increases, consumer demand for the good or service will decrease, and vice versa. It says that the higher the price, the lower the quantity demanded, because consumers' opportunity cost to acquire that good or service increases, and they must make more tradeoffs to acquire the more expensive product. When drawing a demand curve, economists assume all factors are held constant except one - the price of the product itself. A demand curve (figure 2) shows the relationship between the price of an item and the quantity demanded over a period of time. There are two reasons why more is

\footnotetext{
${ }^{10} \mathrm{See}$ http://www.investopedia.com/terms/d/demand theory.asp and http://www.tutor2u.net/economics/reference/, accessed 1 December 2016.

${ }^{11}$ This is the case for mineral fertilizers in poor countries, especially among smallholder farmers whose financial access is limited and serves as justification for various government poverty alleviation programs, including subsidies and tax waiving or reduction.
} 
demanded as price falls: (i) The income effect: There is an income effect when the price of a good falls because the consumer can maintain the same consumption for less expenditure. Provided that the good is normal, some of the resulting increase in real income is used to buy more of this product; (ii) The Substitution Effect: There is a substitution effect when the price of a good falls because the product is now relatively cheaper than an alternative item and some consumers switch their spending from the alternative good or service. This effect is quite inexistent with mineral fertilizers, as real substitutes do not exist. Organic fertilizers are only complementary to mineral fertilizers, and can never replace the latter in large scale crop production.

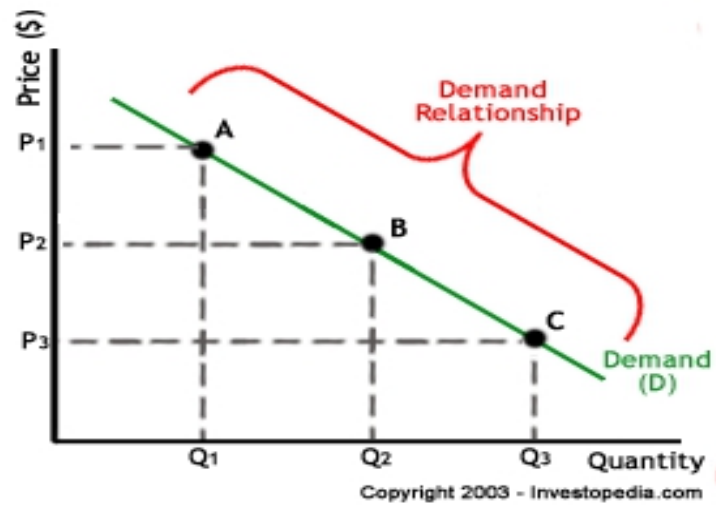

Figure 2: The demand curve

It is also worth recalling the concept of demand elasticity. The percentage change in quantity demanded relative to such a change in price is called price elasticity of demand. Likewise, change in demand relative to income is the income elasticity of demand. Unlike common goods such as food that is offered by a very large number of firms/producers and consumed daily everywhere, the oligopolistic nature of fertilizer supply compared to its high utility among farmers, would make demand very elastic to price, i.e. a slight change in price would provoke non-proportionately larger change in quantity demanded. However, the seasonal nature of fertilizer consumption among West African cotton farmers and the need for them to place orders to traders several months earlier based on crop area estimation, make demand actually inelastic. Fertilizer demand may be elastic in the world market, but it is often inelastic in the domestic market of countries with rain-fed agriculture.

\section{The joint agronomic and marketing perspective}

As demand for food and fiber rises in response to population growth, so does the need for crop nutrients. Mineral fertilizer is the most effective source of nutrients if high crop yields are expected. It is a particular good and its global market is imperfect. Indeed, it is produced only by a few 
manufacturers throughout the world but demanded in all countries willing to develop their agricultural sector. Therefore, there is a high pressure on the international market from leading manufacturers and consumers ${ }^{12}$. Fertilizer is also a chemical product, the production of which requires high technology to transform rare mineral and oil resources (evaporated sea deposits and sea fossils) and is more developed in America (USA mainly), Europe (Norway, France, Netherlands, former Soviet Union). Industrial manufacture ${ }^{13}$ of fertilizers is still timid in Africa, though known to have started several decades ago in South Africa, Morocco and Egypt. In spite of Africa's endowment with mineral resources and oil reserves, the continent's fertilizer production is still lagging behind because it depends mostly on the importation of expensive inputs (ammonia, phosphoric acid), which is a huge constraint to its competitiveness. The impact of fertilizer production and use on the environment vs. their contribution to food security and poverty alleviation, is matter of an ever living debate ${ }^{14}$, which is not worth inviting in this paper.

At farm-level, fertilizer demand is influenced by various agronomic and socio-economic factors, including product-specific attributes and factors of the business environment. The first determinants of fertilizer use intensity include: the intrinsic fertility level or the original nature of soils (Mokwunye, 1996), cropping systems (needs and production objectives) governing area allocation to crops and land cultivation rate that reflect the producer's actual land use capacity (Tshibaka et al., 1992). The average soil degradation rate results from the above three factors and conditions the amount of fertilizer used to compensate for soil nutrients' extraction by crops and, if possible, nutrient losses through leaching, erosion and evaporation. The latters depend on the landscape and land cultivation and fertilizer application practices (van Duivenbooden, 1995; Smaling, 1993). The probability of fertilizer use, or the quantity used depends on farmer's socio-economic conditions, in particular the cultivable land area available and production objectives (cash incomes vs. food self-sufficiency, or both towards food security). It is limited by land suitability for agriculture, and environmental and household constraints (nature of landscape, labor and technology availability, market prices) (Dudal, 2002; Tshibaka et al., 1992; Minot et al., 2000).

Fertilizer demand depends on crop response to fertilizer (agronomic

\footnotetext{
${ }^{12}$ The top five global fertilizer companies, accounting for 33\% of the global market, include: Agrium, CF Industries Holdings, Potash Corporation of Saskatchewan, The Mosaic Company, Yara International. Larger importers/consumers include: Brazil, US, China, and India (source: http://www.lucintel.com/top_five_fertilizer_companies_2012.aspx).

${ }^{13}$ Industrial manufacture refers here to the formal chemical process-based production of soluble fertilizers. Production via bulk-blending is relatively recent.

${ }^{14}$ See for example http://www.livestrong.com/article/139831-the-effects-fertilizers-pesticides/, accessed 4 December 2016; http://www.gpca.org.ae/wp-content/uploads/2014/09/fernexant.pdf, accessed 5 December 2016; Morakinyo et al. (2013), and Roberts and Stewart (2012).
} 
efficiency), input and output prices, and finally the profitability of fertilizer use (financial or economic efficiency) (Breman and Groot, 2004). In socioeconomic studies like this one, its relatively easy and reliable indicator is fertilizer use intensity (i.e. amount of fertilizer per hectare cultivated) on whole farm (all crops). The latter is of the highest importance for the prospects for improving soil fertility and agricultural productivity (Dudal, 2002). The farmer uses past and present information on crop response and profitability from neighbors and agricultural extension workers before deciding on whether or not to use fertilizer, depending on the cropping season (Dèdèhouanou, 2000). In case of a positive decision, these factors - observed this time on his own fields - still condition at the end of the agricultural year his motivation to continue fertilizing his crops at the same intensity or less or more (Semalulu et al., 2014; Williams, 1958). Figure 2 illustrates the causal relationships thus described. Although not exhaustive, it shows how complex the fertilizer demand process is. Highlighted are the factors more or less close to the farmer in his/her decision to buy fertilizer and apply it to improve soil fertility today or tomorrow. Rainfall (i.e. water availability) and crop and fertilizer prices, which are today under unprecedented climate and global market uncertainties, were deemed beyond the control of African farmers and constitute significant risks for fertilizer use (Sanders et al., 1996). Poor farm households with low access to technology and credit are particularly vulnerable and are increasingly excluded from agricultural intensification (Ouédraogo, 2005; Dixon et al., 2001), particularly when market institutions and organizations are failing (Dudal 2002; Dèdèhouanou, 2000). While most experts agree that financial profitability is the ultimate determinant of present or future fertilizer demand, this relationship is only the visible part of the iceberg. Interactions between agronomic and socio-economic factors are still being investigated as to their effect on fertilizer use intensity. In particular, the effect of traders' efficacy (distribution service quality) on fertilizer demand has received some attention.

Adesina and Baidu-Forson (1995) and Dèdèhouanou (2000) revealed the importance of agricultural technology (input, equipment, methods of use) characteristics in its adoption by farmers. However, while physical characteristics of a technology are important, it is also worth investigating the influence of total quality of marketing service on demand. The latter should bear adequate response from the vendor to the consumer's needs in terms of form (intrinsic quality, packaging quality and design), desired time or time and place of delivery. Price should be the result of these attributes, including consumer's sensitivity to advertising or promotion, as the "equilibrium price" of neoclassical theory of the firm suggests. Moreover, according to the utility theory, the price of a good or service is related to its marginal utility and the 
consumer will rank his preferences accordingly ${ }^{15}$. However, in an imperfect market where prices are administered like the cotton fertilizer market in Benin, this may not always be the case. Fertilizer quality and related distribution services are far from being optimal. It is therefore useful to assess the influence of the quality of the distribution service on fertilizer demand, separately from that of price. This study also pays attention to this aspect, in addition to other presumed determinants of demand.

\section{Methodology}

\section{Model specification}

\section{The theoretical demand model in an imperfect market}

According to the microeconomic theory presented earlier, the demand of a good/service is function of its price, the prices of substitutes and complementary goods and the consumer's income. Under the Ceteris paribus assumption the latter factors are held constant, and the demand function in a perfect market relates the quantity demanded only to the price of the good. It writes as follows:

where:

$$
\mathrm{D}=\mathrm{a}-\mathrm{b} . \mathrm{P}
$$

D: the quantity of the good or service the consumer/buyer demands at a given time or over a certain period;

$\mathrm{P}$ : the price set by the seller or the price agreed upon with the seller for the purchase of quantity $\mathrm{D}$;

a: the maximum quantity that the buyer will consume if price is zero or if he could produce the good himself; it depends on the origin $\left(a_{0}\right)$, i.e. the initial quantity he already has and from which he feels the need to get an additional quantity (a) to meet his total desired consumption $\left(\mathrm{D}_{0}\right)$, so that $\mathrm{a}=$ $\mathrm{D}_{0}-\mathrm{a}_{0} ; \mathrm{a}>0$;

- b: slope of the demand curve, i.e. the incremental decrease in the quantity demanded in response to unitary increase in price and vice-versa, according to the law of demand; $b>0$ or $-b<0$.

In an imperfect market, the law of demand still holds. However, firstly the price is more often set by the seller and there is quite little room for the consumer to bargain and pull it down towards his expectation resulting from his knowledge of demand and supply conditions. The consumer's reduced bargaining power (low income or limited physical and social accessibility) and his insufficient knowledge of market conditions place him in the position of price taker. Likewise, it may also happen in an imperfect market that strong consumer associations and/or the government impose price ceilings, which traders/sellers of a strategic good are compelled not to go beyond. Such

\footnotetext{
${ }^{15}$ See : http://www.businessdictionary.com/definition/utility-theory.html accessed ...
} 
ceilings are decided upon, knowing the trends in competitive production and transportation costs, other distribution costs, etc. and a maximum profit rate allowed. Secondly, the Ceteris paribus assumption no more applies. Several factors other than the price of the good itself are now given due attention. They include the prices of substitutes and complementary goods, the consumer's income, and many non-price factors in his household and the business environment. The fertilizer demand model described below draws from the case of an imperfect market.

\section{Variables of the study model and methods of estimation}

The dependent or explained variable in the model is fertilizer demand (D), measured as fertilizer use intensity (amount of fertilizer consumed per hectare cultivated). It is operationalized as the average intensity of use calculated for each study village from the sample of the 577 individual farmers surveyed. The main explanatory variables include, on the one hand, the estimated fertilizer cost price and the distribution service quality and, on the other hand, factors of the business environment which is composed of several vectors. The quality of fertilizer distribution service is assessed from farmers' perceptions of marketing service management by traders. Using the performance scores of conventional marketing services, it is calculated as a composite index of quality, availability and accessibility to fertilizers (See Honfoga 2012, Honfoga 2013). The estimated fertilizer cost price at village store gate is the sum of import price (CIF price) and total local distribution cost from port (Cotonou) to the village. This cost is calculated based on the cost price structure according to the Office of Income Security (ONS) and the competitive transportation costs.

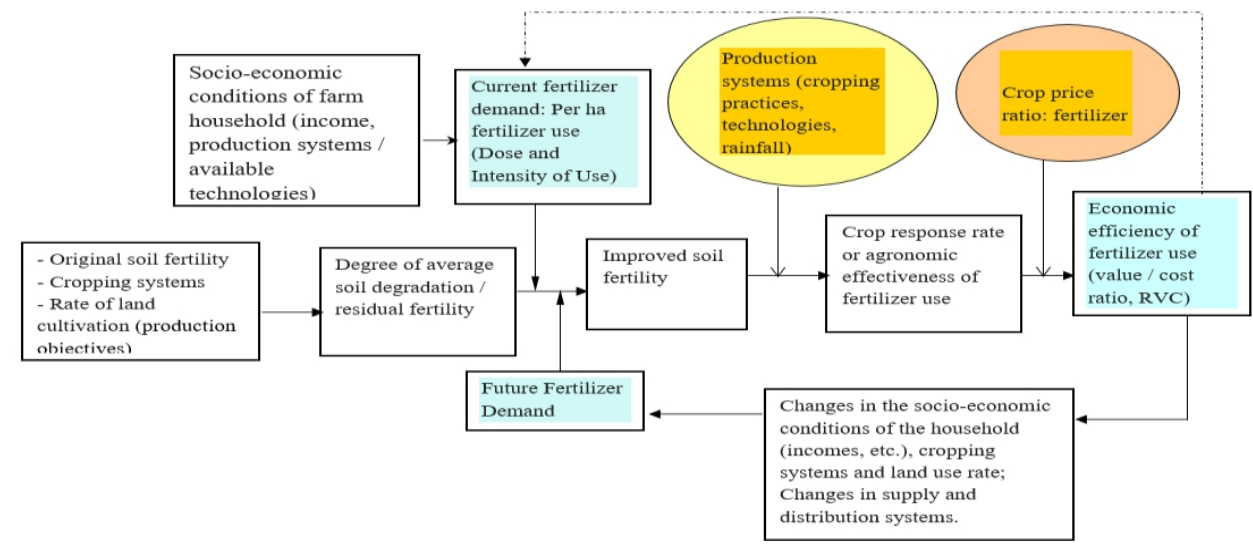

Figure 2: The Fertilizer Demand Process

Source: Honfoga (2007)Three vectors of variables represent the fertilizer business environment. They include factors of the physical environment $(Z)$, institutional factors and agricultural/trade policies (I) and factors of accessibility to agricultural markets (M). These vectors are described as follows: 
Vector Z: soil quality measured by average village soil degradation rate, and the climate risk measured by rainfall variability (algebraic deviation of the first order moving average from the normal over the period 1961-1990).

Vector I: land tenure, degree of orientation of production to exports, liberalization and its effects on the dynamics of distribution companies and farmers, and price distortion caused by the cotton sub-sector administration. These variables are interpreted in the study regions as follows.

- Land tenure: share of rented land area in total available agricultural area;

- Degree of orientation of production towards exports, measured as share of cotton in the total cultivated area in the district;

- Effects of liberalization policy in terms of the impact of fertilizer distribution zone allocation to fertilizer companies by $\mathrm{AIC}^{16}$ on supply dynamics and farmers: They are measured respectively by the relative constancy of companies' intervention (frequency times \% of zones covered), the coefficient of distribution zones' asymmetry, and farmers' appreciation of the impact of liberalization on access to fertilizers;

- Price distortion by the cotton sub-sector administration: difference between the applied cost price and estimated cost price, adjusted for transport costs. This is as an estimate of hidden profits and rents in the distribution system.

Vector M: factors of agricultural markets' accessibility, including:

M1: accessibility to agricultural knowledge market, represented by diffusion rates of complementary technologies (improved maize seed, organic matter and soil and water conservation techniques).

M2: physical and financial accessibility to the fertilizer market, represented by transportation and storage infrastructures (density of rural roads, farmer's assessment of roads' state, distance from district central warehouse to village store, average distance from village store to farmer's fields, capacity ratio of stores in good condition), financial accessibility (offfarm income per hectare cultivated and agricultural credit).

M3: agricultural produce market accessibility, represented by transportation difficulty (distance from house to market) and the importance of agricultural produce processing (number of processing mills in the village).

\section{The regression equation}

In application of the theoretical demand model in an imperfect market, the multiple regression equation expressing the mathematical form of the model is first supposed to be linear and is written as follows:

${ }^{16}$ This was done through CAGIA, the AIC agricultural input branch. 


$$
\begin{aligned}
& D_{i, j, t}=f\left(P_{i, j, t}, Q_{i, j, t}, Z_{i, j, t}, I_{i, j, t}, M_{i, j, t}\right) \\
& D_{i, j, t}=a+b \cdot P_{i, j, t}+\theta \cdot Q_{i, j, t}+\alpha \cdot Z_{i, j, t}+\beta \cdot I_{i, j, t}+\gamma \cdot M_{i, j, t}+\varepsilon
\end{aligned}
$$

where:

$D_{i, j, t}$ is the demand for fertilizer or intensity of fertilizer use in village $i$ of commune $\mathrm{j}$ in year $\mathrm{t}$;

$\mathrm{REG}_{\mathrm{i}, \mathrm{j}, \mathrm{t}}$ : Dummy of the region (1: Borgou-Alibori and 0: Zou-Collines), whatever t;

$\mathrm{Q}_{\mathrm{i}, \mathrm{j}, \mathrm{t}}=$ Index of the quality of the ISV distribution service in village $\mathrm{i}$ of commune $\mathrm{j}$ in year $\mathrm{t}$;

$\mathrm{P}_{\mathrm{i}, \mathrm{j}, \mathrm{t}}=\mathrm{Pf}_{\mathrm{i}, \mathrm{j}, \mathrm{t}}+\Delta_{\mathrm{i}, \mathrm{j}, \mathrm{t}}=$ Estimated cost of fertilizer at the village $\mathrm{i}$ store in commune $\mathrm{j}$ in year $\mathrm{t}$

$\mathrm{Pf}_{\mathrm{i}, \mathrm{j}, \mathrm{t}}=$ Supplier price or CIF price of fertilizer in port, for importer / distributor who supplied village $i$ in commune $j$ in year $t$

$\Delta_{\mathrm{i}, \mathrm{j}, \mathrm{t}}=$ Estimated total distribution cost (actual marketing costs + distributor profit);

$T_{i, j, t}=$ Fertilizer transport costs from port to village $i$ in commune $j$ in year $t$; $\mathrm{Z}_{\mathrm{i}, \mathrm{j}, \mathrm{t}}$ : Vector of factors of the physical environment of the study area

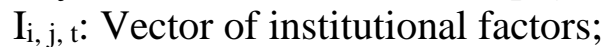

$\mathrm{M}_{\mathrm{i}, \mathrm{j}, \mathrm{t}}$ : Vector of factors of accessibility to agricultural markets;

i: Observation villages, $\mathrm{i}=1 . . \mathrm{n}(\mathrm{n}=191)$;

$\mathrm{j}$ : District which the villages belong to (zonal unit for policy and local trade dynamics data), $\mathrm{j}=1 . . \mathrm{m}(\mathrm{m}=14)$;

t: Years to which farmers' data refer to, $t=1,2$ for 2003, 2004;

a: The constant

b: Parameter of the variable "estimated fertilizer cost price";

$\theta$ : Parameter of the variable "distribution service quality"

$\alpha$ : Vector of the parameters of physical environment factors

$\beta$ : Vector of parameters of institutional and policy factors

$\gamma:$ Vector of market accessibility factors

$\varepsilon$ : Error term.

It is important to notice that not all the variables composing vectors $\mathrm{Z}$, $\mathrm{I}$ and $\mathrm{M}$ are measured at the same level of observation: four were measured at district level (j) and the 21 other explanatory variables and the dependent variable at the village level (i). The time $t$ (year) was introduced mainly to reflect annual variability of price and distribution dynamics, fertilizer use intensity and technological variables. This implies the replication of $\mathrm{j}$ and $\mathrm{t}-$ levels variables over i-level variables (village observations). For the sake of simplicity, the same index $(i, j, t)$ is assigned to the vectors, meaning each observation of all variables are applicable to village $i$ of district $j$ at time $t$. In 
addition, the 'dummy' variable of the 'Region' (REG) is introduced to reflect the notable differences in fertilizer use between the two regions of the study. Regardless of year $t$, the dummy variable takes the value 1 for districts in the Borgou-Alibori region (with reference to the favorable cotton policy bias for fertilizer use) and 0 for Zou-Collines. Considering the role of 'dummy' variables in social sciences and despite some limitations about their use, such as the relative effect on the regression equation's constant depending on their number and the choice of dichotomous values (0 / 1 vs. 1 / 2 for example) (Suits 1957), the inclusion of the region 'dummy' was deemed very useful for our analysis for above-mentioned reasons.

The signs of variables' coefficients are predicted as follows:

a $>0$, because there will be at least one village where a farmer consumes fertilizer;

$\mathrm{b}<0$, according to the law of demand (fertilizer consumption decreases when the cost price increases);

$\theta>0$, according to the marketing theory (fertilizer demand increases with distribution service quality);

$\alpha, \beta, \gamma>0$ with the assumption that all factors in a favorable environment contribute a priori to increasing demand.

A semi-logarithmic transformation is applied to equation (2) by regressing the explanatory variables against the natural logarithm of demand. Indeed, the semi-log form presents general results more significant than the linear form: much higher values of $\mathrm{F}$ and adjusted R2. Our model's specificity, compared to others (Minot et al., 2000; Ouédraogo, 2002), is to analyze fertilizer demand under a joint agronomic and marketing perspective.

\section{Data used and methods of collection}

Data used proceed from a research conducted from 2003 to 2007 on fertilizer distribution in the liberalized cotton sub-sector in Benin. A field survey was done in the two main cotton-producing regions (Zou-Collines (ZC) in the center and Borgou-Alibori (BA) in the north) to collect primary data on fertilizer use and farmers' evaluation of fertilizer marketing services. The sample was made of 577 farmers selected in 191 villages of 14 districts (8 in ZC and 6 in BA). Districts and villages were chosen purposively taking into account different levels of fertilizer use, crop production diversity and levels of soil degradation. Two to five farmers were randomly chosen from lists of members of village cotton farmers' cooperatives, using multiple/successive draws so as to get small-, medium- and large-scale farmers according to area cultivated. The resulting sample was therefore representative of cotton-producing villages in the two zones. Selected farmers were interviewed on: (a) their technical skills in fertilizer use, (b) how they rate (poor or good) the marketing services that are presently offered to them 
by traders under the licensing system, and (c) what improvements or different needs in future service delivery they desire.

The fertilizer use aspect of the survey addressed technological variables (area cultivated, area and crops fertilized, fertilizers quantities, doses of application, intensity of fertilizer use, rate of diffusion, complementary inputs/technologies, etc.). The service quality aspect or marketing survey addressed the total quality of marketing services. For both components of the survey, farmers were interviewed from October 2004 to February 2005 using structured questionnaires, while non-structured interviews were held with traders and national-level organizations and institutions involved in fertilizer distribution in Benin. These include traders' organizations and the cotton subsector's administration which holds the licensing system. Additional qualitative information was also obtained from secondary sources.

Data used for the regression analysis are village-level averages of farm-level primary data, combined with district-level secondary data. The regression data matrix finally had 382 observations $(n=191$ villages $* 2$ years =382). The 191 villages were taken as observation units in order to reduce the high autocorrelation which would be observed if district-level data were replicated/distributed over the 577 farmers surveyed. The analysis covered the marketing survey year 2004/05 and the previous year (2003/04) to harness the most recent and reliable fertilizer consumption recall from farmers. During the first year there was a slump in the cotton international market and a drastic decline in fertilizer consumption everywhere in the country, but more severely in the central region. The second year was a recovery year marked with greater AIC incentives to cotton farmers.

\section{Results and discussion}

\section{Status of the regression model variables and parameters}

Table 2 reports descriptive statistics (minimum, maxima, mean, standard deviations) of the model's variables. Table 3 presents the state of the regression matrix which was sufficiently complete (on average $95.5 \%$ of valid observations for all variables over the total of 382 observations) to allow the regression analysis. Table 4 presents the coefficients of correlation between some variables of the model. These correlation coefficients are significant at $\mathrm{p}<0.0001$, indicating a strong collinearity between the variables concerned. These results suggest that there are interactions between the obvious variables characterizing the distribution service (estimated cost price, quality of service) and those of the business environment (adjusted difference between estimated and applied price, dummy of the region, share of cotton in the cultivated area, density of rural tracks). These interactions are inevitable. The results of the regression analysis, after missing values' substitution by means are presented in Table 5. They were obtained with the GLM procedure of the 
SAS software. The estimated equation has a very high significance $(\mathrm{F}=16.4$, $\mathrm{R} 2=0.5365$, significance level: $<0.0001)$. The Durbin-Watson test $(\mathrm{DW}=$ 2.4) indicates that the degree of interactions between explanatory variables is tolerable. Moreover, on the one hand the coefficients of a majority of these variables are significant and have the predicted signs. On the other hand, the negative sign of the service quality index coefficient is contrary to the prediction. This result reflects the regional polarization of the fertilizer supply policy, regardless of cotton farmers' judgment on the quality of marketing services. Although the coefficient is not significant, the results suggest that the quality of distribution service through the licensing system is unfavorable to fertilizer demand. Indeed, while the cotton administration claims to offer equal services under a uniformed distribution policy (unique spatial organization and fixed timelines for procurement), in reality the service appreciation by cotton farmers is discordant with current demand, as explained earlier in the study context description.

\section{Main determinants of fertilizer demand among cotton farmers}

The most critical determinants of fertilizer demand (with coefficients significant at $5 \%$ or $1 \%$ level) include:

- dummy of the region: It confirms the very sensitive effect of the biased fertilizer distribution policy in favor of the northern cotton zone. The favorable climate together with the cotton-biased policy makes the northeastern zone a favorable zone for distributors and for fertilizer consumption by farmers. Unlike the central zone where farmers pay more than reasonable prices, the former benefits from a disguised higher subsidy.

- share of cotton in cultivated area: It appears to be an important driver of fertilizer consumption. Its importance is attributable to the above policy, but mainly to the foreign market orientation of cotton production, with related marketing facilities offered to growers. - density of rural roads: It is one of the most important determinants of fertilizer consumption. The higher it is, the easier fertilizer transportation, and the higher is consumption.

- average distance from village fertilizer store to farmer's fields: This is a factor that has a significant negative influence on fertilizer use intensity, as Zhou et al. (2010) and Liu et al. (2009) also found it. It reduces farmers' incentive to use fertilizers due to poor road conditions and high transportation cost to the fields. In Benin, the licensing system and its private distributors ignore this cost, as their service stops at district store gate. They do not deal with individual farmers and therefore do not offer cost-effective service.

- off-farm income per hectare cultivated: It plays a very significant positive effect on the demand for fertilizer and agricultural technology in general. Diiro (2013) found a positive and significant association between off- 
farm income and the proportion of land planted with improved maize varieties. In fertilizer use, off-farm income is mainly used to finance other production costs (wage labor for weeding, fertilizer application, pest control and crop harvesting), which increase with the amount of fertilizer used (Tshibaka et al., 1992). But the need for wage labor depends on the amount and quality of available family labor, and farmers with higher off-farm income may have lower technical efficiency (Diiro, 2013).

Table 2: Descriptive statistics of the regression model variables

\begin{tabular}{|c|c|c|c|c|c|c|}
\hline Variables & Level & $\begin{array}{c}\text { Unit / } \\
\text { Gradient }^{\text {a }}\end{array}$ & Min & Max & Mean & Std \\
\hline \multicolumn{7}{|c|}{ Dependent variable } \\
\hline $\begin{array}{c}\text { Fertilizer use } \\
\text { intensity (per ha } \\
\text { consumption) }\end{array}$ & $\mathrm{i}, \mathrm{t}$ & $\mathrm{Kg} / \mathrm{ha}$ & 1.50 & 308.20 & 122.56 & 57.78 \\
\hline $\begin{array}{c}\text { Natural log of per ha } \\
\text { consumption }\end{array}$ & & & 0.41 & 5.73 & 4.62 & 0.76 \\
\hline \multicolumn{7}{|c|}{ Explanatory variables } \\
\hline Estimated cost price & $\mathrm{i}, \mathrm{t}$ & FCFA/kg & 165.20 & 237.30 & 193.65 & 19.27 \\
\hline Service quality index & & $0-1$ & 0.083 & 0.813 & 0.572 & 0.125 \\
\hline $\begin{array}{l}\text { Rate of soil } \\
\text { degradation }\end{array}$ & $\mathrm{i}$ & $\%$ & 2.60 & 100 & 32.65 & 23.00 \\
\hline Dummy of the region & & $0 / 1$ & 0 & 1 & - & - \\
\hline Variability of rainfall & $\mathrm{j}, \mathrm{t}$ & $\%$ & -6.30 & 15.30 & 4.17 & 6.48 \\
\hline $\begin{array}{c}\text { Proportion of leased } \\
\text { area }\end{array}$ & $\mathrm{i}$ & $\%$ & 0 & 100 & 5.37 & 12.32 \\
\hline $\begin{array}{l}\text { Share of cotton in } \\
\text { cultivated area }\end{array}$ & $\mathrm{i}, \mathrm{t}$ & $\%$ & 0 & 84.40 & 40.48 & 20.41 \\
\hline $\begin{array}{l}\text { Relative constancy of } \\
\text { intervention }\end{array}$ & $\mathrm{j}, \mathrm{t}$ & $\%$ & 0 & 55.8 & 40.07 & 21.20 \\
\hline $\begin{array}{c}\text { Asymmetry } \\
\text { coefficient of } \\
\text { intervention zones }\end{array}$ & $\mathrm{j}, \mathrm{t}$ & & 0,10 & 2.90 & 1.22 & 1.05 \\
\hline $\begin{array}{l}\text { Impact of } \\
\text { liberalization } \\
\text { (farmers' } \\
\text { assessment) }\end{array}$ & $\mathrm{i}, \mathrm{t}$ & $0,1,2$ & 0.00 & 2.00 & 1.13 & 0.54 \\
\hline $\begin{array}{l}\text { Applied-estimated } \\
\text { cost differential }\end{array}$ & $\mathrm{i}, \mathrm{t}$ & $\mathrm{FCFA} / \mathrm{kg}$ & -11.31 & 31.70 & 10.92 & 9.39 \\
\hline $\begin{array}{c}\text { Diffusion rate, } \\
\text { hybrid maize seeds }\end{array}$ & $\mathrm{i}, \mathrm{t}$ & $\%$ & 0 & 100 & 13.44 & 17.01 \\
\hline $\begin{array}{l}\text { Diffusion rate, } \\
\text { organic matter }\end{array}$ & $\mathrm{i}, \mathrm{t}$ & $\%$ & 0 & 68.5 & 3.84 & 8.92 \\
\hline $\begin{array}{c}\text { Diffusion rate, CES } \\
\text { techniques }\end{array}$ & $\mathrm{i}, \mathrm{t}$ & $\%$ & 0 & 100 & 14.18 & 21.36 \\
\hline $\begin{array}{c}\text { Density of rural } \\
\text { roads }\end{array}$ & $\mathrm{j}$ & $\begin{array}{c}\mathrm{Km} / 10^{4} \\
\text { inhabitants }\end{array}$ & 0.80 & 9.10 & 4.02 & 2.78 \\
\hline
\end{tabular}




\begin{tabular}{|c|c|c|c|c|c|c|}
\hline $\begin{array}{c}\text { State of rural roads } \\
\text { (farmers' } \\
\text { assessment) }\end{array}$ & $\mathrm{i}$ & $0,1,2$ & 0.00 & 2.00 & 0.23 & 0.44 \\
\hline $\begin{array}{c}\text { Distance 'district } \\
\text { warehouse - village } \\
\text { store' }\end{array}$ & $\mathrm{i}$ & $\mathrm{km}$ & 0.70 & 82.00 & 19.23 & 14.80 \\
\hline $\begin{array}{c}\text { Average distance } \\
\text { 'village store - } \\
\text { farmer fields' }\end{array}$ & $\mathrm{i}$ & $\mathrm{km}$ & 0.00 & 32.00 & 6.27 & 4.76 \\
\hline
\end{tabular}

Table 2: Descriptive statistics of the regression model variables (continued)

\begin{tabular}{|c|c|c|c|c|c|c|}
\hline Variables & Level & $\begin{array}{c}\text { Unit / } \\
\text { Gradient a }^{\text {a }}\end{array}$ & Min & Max & Mean & Std \\
\hline $\begin{array}{c}\text { Capacity ratio of } \\
\text { stores in good } \\
\text { condition }\end{array}$ & $\mathrm{j}$ & $\%$ & 0.00 & 100.00 & 84.89 & 29.87 \\
\hline Off-farm income & $\mathrm{i}, \mathrm{t}$ & FCFA/ha & 250.00 & 349412 & 26042.0 & 34707.80 \\
\hline $\begin{array}{c}\text { Employed labor } \\
\text { force }\end{array}$ & $\mathrm{i}, \mathrm{t}$ & $\mathrm{FCFA} / \mathrm{ha}$ & 0.00 & 201972.00 & 16427.60 & 16259.00 \\
\hline CLCAM credit & $\mathrm{i}, \mathrm{t}$ & $\mathrm{FCFA} / \mathrm{ha}$ & 952.40 & 94269.00 & 16880.70 & 12518.00 \\
\hline Net farm income b & $\mathrm{i}, \mathrm{t}$ & $\mathrm{FCFA} / \mathrm{ha}$ & 312.50 & 305333.00 & 63639.10 & 44799.90 \\
\hline $\begin{array}{c}\text { Distance 'house - } \\
\text { village market' }\end{array}$ & $\mathrm{i}$ & $\mathrm{km}$ & 0 & 45 & 7.92 & 9.41 \\
\hline $\begin{array}{c}\text { Number of food } \\
\text { mills in village }\end{array}$ & $\mathrm{i}$ & $\begin{array}{c}\text { number/10 } \\
\text { inhabitants }\end{array}$ & 0.30 & 120.00 & 14.87 & 15.91 \\
\hline
\end{tabular}

a / ha = per ha cultivated.

${ }^{\mathrm{b}}$ Net income from sales of agricultural products (cotton revenue - input debts + sales of other agricultural products)

Source: Survey data.

Table 3: Structure of the regression matrix data

\begin{tabular}{|c|c|c|}
\hline Variables & $\begin{array}{c}\text { Number of valid } \\
\text { observations }\end{array}$ & $\begin{array}{c}\% \text { missing } \\
\text { observations }\end{array}$ \\
\hline $\begin{array}{c}\text { Off-farm income, CLCAM credit, net farm } \\
\text { income, capacity ratio of stores in good } \\
\text { condition }\end{array}$ & $255-314$ & $18-33$ \\
\hline $\begin{array}{c}\text { Proportion of leased land, natural } \\
\text { logarithm of fertilizer use intensity }\end{array}$ & $362-366$ & 1 \\
\hline $\begin{array}{c}\text { Distance from village fertilizer store to } \\
\text { farmer's fields, distance from house to } \\
\text { fields, organic matter diffusion rate, CES } \\
\text { diffusion rate, cotton share in cultivated } \\
\text { area, impact of liberalization, condition of } \\
\text { rural roads, number of mills }\end{array}$ & $378-380$ & \\
\hline Others (13) & 382 & 0 \\
\hline Average & 365 & 4 \\
\hline
\end{tabular}

Source: Survey data. 
Table 4: Pearson coefficients of correlation between a few variables after substitution by means*

\begin{tabular}{|c|c|c|c|c|c|c|}
\hline & $\begin{array}{c}\text { Dummy } \\
\text { (REG) }\end{array}$ & $\begin{array}{c}\text { Share } \\
\text { cotton in } \\
\text { area } \\
\text { (PCOT) }\end{array}$ & $\begin{array}{c}\text { Density } \\
\text { of rural } \\
\text { roads } \\
\text { (DPR) }\end{array}$ & $\begin{array}{c}\text { Service } \\
\text { Quality } \\
\text { Index } \\
\text { (ISV) }\end{array}$ & $\begin{array}{c}\text { Estimated } \\
\text { cost price } \\
\text { (PRE) }\end{array}$ & $\begin{array}{c}\text { Adjusted } \\
\text { cost } \\
\text { differential } \\
\text { (ECART) }\end{array}$ \\
\hline REG & 1 & 0.471 & -0.841 & -0.722 & 0.935 & -0.556 \\
\hline PCOT & & 1 & -0.337 & -0.232 & 0.417 & -0.261 \\
\hline DPR & & & 1 & $\mathbf{0 . 5 0 6}$ & $\mathbf{- 0 . 7 2 4}$ & 0.483 \\
\hline ISV & & & & 1 & $\mathbf{- 0 . 7 7 7}$ & 0.483 \\
\hline PRE & & & & & 1 & -0.685 \\
\hline ECART & & & & & & 1 \\
\hline
\end{tabular}

* All coefficients are significant at $\mathrm{p}<0.0001$

Source: Survey data.

Table 5: Parameters of the semi-log fertilizer demand regression model

\begin{tabular}{|c|c|c|c|c|}
\hline Explanatory variables & Name & Coefficient & $\begin{array}{l}\text { Student } \\
\text { t-value }\end{array}$ & $\operatorname{Pr}>|\mathrm{t}|$ \\
\hline Constant & & $5.52464^{* * *}$ & 3.75 & 0.0002 \\
\hline Estimated cost price at village store gate & $P R E$ & $-0.01207^{b}$ & -1.56 & 0.1187 \\
\hline Service quality index at village level & ISV & $\underline{-0.14121}$ & -0.55 & 0.5816 \\
\hline Dummy of the region & REG & $1.1366^{* * *}$ & 4.48 & $<0.0001$ \\
\hline Soil degradation rate at farm level & $P T D P$ & $-0.00251^{a}$ & -1.73 & 0.0851 \\
\hline Variability of rainfall & PLVA & -0.00772 & -1.02 & 0.3108 \\
\hline Proportion of leased area by the farmer & PTLP & $\underline{0.00457^{*}}$ & 1.98 & 0.0481 \\
\hline Share of cotton in cultivated area & PCOT & $0.01963^{* * * *}$ & 10.81 & $<0.0001$ \\
\hline Relative constancy of intervention & CRI & -0.00028 & -0.09 & 0.9282 \\
\hline Asymmetry of the intervention zones & SKW & -0.022495 & -0.56 & 0.5743 \\
\hline Impact of liberalization & ILAA & -0.02267 & -0.42 & 0.6735 \\
\hline Applied-estimated cost d & ECART & 0.30158 & 1.11 & 0.2926 \\
\hline Diffusion rate, hybrid maize seeds & SAM & 0.00177 & 1.01 & 0.3147 \\
\hline Diffusion rate, organic matter & MOG & -0.00025 & -0.01 & 0.9942 \\
\hline Diffusion rate, CES techniques & CES & $0.00226^{b}$ & 1.54 & 0.1248 \\
\hline Density of rural roads & DPR & $0.06716^{* *}$ & 2.40 & 0.0167 \\
\hline State of rural roads (farmers' assessment) & PIRA & 0.03015 & 0.44 & 0.6614 \\
\hline $\begin{array}{c}\text { Distance 'district warehouse - village } \\
\text { store' }\end{array}$ & DCV & 0.00305 & 1.15 & 0.2522 \\
\hline $\begin{array}{c}\text { Average distance 'village store - farmer } \\
\text { fields' }\end{array}$ & DMC & $-0.01805^{* *}$ & -2.96 & 0.0033 \\
\hline Capacity ratio of stores good condition & CMB & -0.00037 & -0.39 & 0.7003 \\
\hline Off-farm income & RXHA & $2.35 \mathrm{E}-6^{* *}$ & 2.75 & 0.0064 \\
\hline Employed labor force & MOSHA & $2.13 \mathrm{E}-6$ & 1.13 & 0.2585 \\
\hline CLCAM credit & EPAHA & $1.99 \mathrm{E}-6$ & 0.82 & 0.4153 \\
\hline Net farm income & RAGHA & $-0.5 \mathrm{E}-8$ & -0.01 & 0.9990 \\
\hline Distance 'house - village market' & $D M M A$ & $-0.00485^{b}$ & -1.47 & 0.1437 \\
\hline Number of food mills in village & MTPA & 0.00031 & 0.16 & 0.8702 \\
\hline
\end{tabular}

Model's general significance level: $\mathrm{F}=16,48^{* * *} ; \mathrm{R}^{2}=0,5365 ; \mathrm{DW}=2.4 ; \mathrm{P}<0.0001$.

Coefficient's significance level or probability of null hypothesis $(\mathrm{b}=0)$ acceptance: *** $0.1 \%$ or less; $* * 1 \%$; $* 5 \%$; ${ }^{\text {a }} 10 \%$; ${ }^{\mathrm{b}}$ above $10 \%$.

Number of observations: 382 . 

level,

Other variables that influence fertilizer demand, at $10 \%$ significance

- estimated cost price, the coefficient of which obeys well to the negative sign prediction, agreeing with the theory of demand. Despite the administration of prices through the licensing system, the real farm-gate price has a negative influence on fertilizer demand. - soil degradation rate is unfavorable to fertilizer use intensity, meaning farmers reduce the amount of fertilizer per ha cultivated when soils become less and less fertile. This should be the normal behavior. Zhou et al. found that soil fertility is negatively correlated with fertilizer use intensity in Chaobai (China), i.e. less fertilizer is used per ha of very fertile lands, and vice-versa.

- rate of diffusion of water and soil conservation techniques (CES): It is favorable fertilizer consumption, which is high in localities where CES techniques are largely disseminated, especially the northern cotton areas where rural development projects popularized these techniques to mitigate the growing soil degradation.

- proportion of leased land area: The positive sign of its coefficient reflects the beneficial influence of land leasing on fertilizer consumption in cotton-growing areas. In these zones, tenants are not concerned about the precariousness of their investment, as cotton income is quite guaranteed. This is contrary to the commonly held view that land leasing is unfavorable to fertilizer consumption. Such idea stems from the presumption that land tenants would not be willing to invest in improving soil fertility for fear of landlords claiming back their land a few years after the investment. It is quite the opposite in the cotton zones of Benin, especially in the central region where population pressure is high while cotton, together with maize which also is increasingly being exported, thereby providing a strong motivation for fertilizer use.

- distance from cotton grower's house to local agricultural market: The higher it is, the lower is fertilizer use intensity. It is worth recalling that much of cotton fertilizer is used for "food crops", which are usually sold in local markets. Among them, maize has become a real cash crop that discretely dictates the use of cotton fertilizers (the only ones available) through the cotton-maize crop rotation. The more cotton farmers have trouble selling maize, the less they will use fertilizers.

Other remaining variables in the model are not significant and therefore have a negligible influence on fertilizer demand. In particular, the quality of distribution service index has very little influence on fertilizer demand. Either its influence is already contained in that of price, or its variability in the licensing system is not enough to effect fertilizer demand. 


\section{Implications of results for fertilizer policy-making}

The above results highlight the levers of an effective policy that would considerably boost fertilizer use intensity in Benin. In relation with the main fertilizer demand determinants, avenues for fertilizer policy improvement would include:

- development of road and market infrastructures: The positive and very significant influence of rural roads' density on fertilizer consumption indicates the urgent need to develop road infrastructures. Government's efforts to increase the density of rural roads should be encouraged. Indeed, fertilizer consumption areas that were difficult to reach at the time of the survey account for about $60 \%$ total cultivated area. Opening-up cotton production areas such as Banikoara, Sinendé, Segbana, Djidja, Za-Kpota, etc. with all-season practicable roads is a major emergency. Recently, the government has bituminized the Kandi-Banikoara and Kandi-Segbana roads, which were very bad roads until 2007. This effort should be continued in other cotton producing areas, especially for village access roads.

- market orientation of farming and the development of off-farm activities:

Considering the new trade opportunities in West Africa, the private sector should be encouraged to develop the tradability of food crops. There is a need to promote processing of crude farm products and rural handicrafts in order to increase farmers' purchasing power and their fertilizer use propensity for increased agricultural production.

- improving fertilizer distribution policies and institutions: The Dummy of the region and the share of cotton in total cultivated area show the influence of regional cotton-biased policies on fertilizer consumption. Institutional reforms to meet the fertilization needs of all major crops are needed to slow down soil degradation. Thus, the State should consider a more accountable mechanism to accompany the process of market liberalization, rather than perpetuating the licensing system that indirectly restricts areas and crops that have access to fertilizers. - liberalization of the retail market for fertilizers and capacity building for distributors:

The farm-gate cost of fertilizers remains an important determinant of fertilizer use intensity. This indicates the need for a better fertilizer supply and distribution system, that would lead to reducing distribution costs through fair competition. Indeed, the licensing system maintains administrative obstructions to competition through arbitrary blockages of entry into the market and the standardization of supply services. In the future, the liberalization of fertilizer retail market would need to deserve a positive attention. Independent rural entrepreneurs should be encouraged to implement more flexible contracts with smallholder farmers for the sale of various types 
of economically profitable fertilizers in their cropping systems.

\section{Conclusion}

The study findings reveal that the price that cotton farmers actually bear at farm-gate still plays a meaningful role in their demand for fertilizers, in spite of the centralized distribution system. While fertilizer price was administered until the village store level, with various degrees of district and village cooperatives' implication in the institutional arrangement with traders, the farm-gate cost price of fertilizers remained a non-negligible factor influencing fertilizer use intensity. This finding highlights the need to develop road and market infrastructures. The significant influence of the density of rural roads on demand, and its strong positive correlation with the quality of distribution service are joint evidence of this need. Concurrently, other critical non-price factors in the farm household (mainly off-farm income) and in the business environment (mainly density of rural roads and distance from village fertilizer store to farmer's fields) deserve greater attention to improve farmers' access and increase their demand for fertilizers. Liberalization of the fertilizer retail market also deserves an urgent positive attention. The purposive administrative obstructions to competition perpetuated by the licensing system should be swiftly addressed. Future policies would also need to enhance market orientation of farming, to develop off-farm activities, and to improve institutional reforms whereby fertilization needs of all major crops in cotton production systems could be met.

\section{References:}

1. Adesina A.A. \& Baidu-Forson, J. (1995). Farmers' perceptions and adoption of new agricultural technology: evidence from analysis in Burkina Faso and Guinea, West Africa. Agricultural Economics, Vol. 13: 1, Elsevier Science B.V., The Netherlands.

2. Agossou V., 1983. Les sols béninois et leurs potentialités agricoles. Projet Agro- Pédologie, Etude $\mathrm{N}^{\circ} 260,10$ p + annexes. INRAB, Bénin.

3. Ahohounkpanzon, M. \& Zakari Allou, Y. (2010). Etude sur les mécanismes de fixation du prix du coton graine et la prise en compte des co-produits du coton au Bénin. Rapport Final, IFDC/WACIP Bamako, Mali.

4. Bessou, R. (2013). Effets du projet d'assainissement et de relance de la Filière coton au Bénin (PARFCB) sur la production cotonnière dans la Commune de Dassa-Zoumè. Mémoire de Master, Institut International de Management (IIM), Cotonou, Bénin. 
5. Bidaux, A. \& Soule, B.G. (2005). Etude sur le mécanisme d'approvisionnement et de distribution des intrants agricoles au Bénin. Document de restitution. AIC, novembre 2005.

6. Breman, H. \& Groot. J.J.R. (2004). The role of fertilizers in agricultural development in Sub-Saharan Africa. Fertilizer Focus, May/June 2004.

7. CIPB (Conseil des Investisseurs Privés au Bénin) (2007). Le Coton dans le Monde, en Afrique et au Bénin. CIPB, Cotonou. www.cipb.bj

8. Coughlan, A., Anderson, E., Stern, L. \& El-Ansary, A. (2001). Marketing Channels. Prentice Hall, New Jersey, 590 p.

9. Dèdèhouanou, H. (2000). Agricultural technology transfer under transaction costs: a Benin's case study in Alphonso Ogbuehi and Gabriel Ogunmokun (eds), 2000 Proceedings, The global challenge of African business and economic development in the New Millenium, International conference, April 11-14, 2000; Atlantic City, New Jersey - USA; pp. 235-241.

10. Dedehouanou, H. (2003). Resisting reforms: a resource-based perspective of collective action in the distribution of agricultural input and primary health services in the Couffo region, Bénin in Research Report 68/2003, African Studies Centre; Leiden; The Netherlands.

11. Diiro, G.M. (2013). Impact of off-farm Income on Agricultural Technology Adoption Intensity and Productivity. Evidence from Rural Maize Farmers in Uganda. IFPRI Uganda Strategy Support Program. Working Paper 11, January 2013.

12. Dixon, J., Gulliver, A. \& Gibbon, D. (2001). Systèmes de production agricole et pauvreté : Améliorer les moyens d'existence des agriculteurs dans un monde en changement - Résumé. FAO / Banque Mondiale, Rome et Washington.

13. Druilhe, Z. \& Barreiro-Hurlé, J. (2012). Fertilizer subsidies in subSaharan Africa. ESA Working paper No. 12-04. FAO, Rome.

14. Dudal, R. (2002). Forty years of soil fertility work in Sub-Saharan Africa. In Vanlauwe, B., Diels, J., Sanginga, N. \& Merckx, R. (Eds.) Integrated Plant Nutrient Management in Sub-Saharan Africa. CAB International 2002.

15. Duivenbooden (van), N. (1995). Land use systems analysis as a tool in land use planning, with special reference to North and West African 
agro-ecosystems. Doctoral thesis, Wageningen Agricultural University, Wageningen, The Netherlands.

16. Ellis, F. (1992). Agricultural policies in developing countries. Cambridge: Cambridge University Press.

17. FAO/IFA (2000). Stratégies en matière d'engrais. FAO, Rome.

18. Honfoga, B.G. (2012). Segmentation du marché d'engrais minéraux pour répondre aux besoins des cotonculteurs au Benin. Bulletin de la Recherche Agronomique du Bénin (BRAB), Numéro spécial Coton - Septembre 2012, pp. 12-25 (site web http://www.slire.net)

19. Honfoga, B.G. (2013). Cotton institutions and perverse incentives for fertilizer traders with the licensing system in Benin. Journal of Development and Agricultural Economics, (5)(1) 19-34. Available online at http://www.academicjournals.org/JDAE DOI: 10.5897/JDAE12.120, ISSN 2006- 9774 (C2013 Academic Journals

20. Igue, M.A, Oga, A.C., Balogoun, I., Saidou, A., Ezui, G., Youl, S., Kpagbin, G., Mando, A. \& Sogbedji, J.M. (2016). Détermination des formules d'engrais minéraux et organiques sur deux types de sols pour une meilleure productivité du maïs (Zea mays 1.) dans la Commune de Banikoara (Nord-Est du Bénin). European Scientific Journal October 2016 volition No. No. URL:http://dx.doi.org/10.19044/esj.2016.v12n30p362.

21. Klein, M.U. \& Hadjimichael, B. (2003). The private sector in development - Entrepreneurship, regulation, and competitive disciplines. A World Bank's publication.

22. Liu, Y., Zhang, J-B. \& Du, J. (2009). Factors Affecting Reduction of Fertilizer Application by Farmers: Empirical Study with Data from Jianghan Plain in Hubei Province. Contributed Paper prepared for presentation at the International Association of Agricultural Economists Conference, Beijing, China, August 16-22, 2009.

23. Minot, N., Kherallah, M. \& Berry, P. (2000). Fertilizer market liberalization in Benin and Malawi - A household-level view. International Food Policy Research Institute (IFPRI), Washington $D C, U S A$.

24. Mokwunye, U.A., de Jager, A. \& Smaling, E.M.A. (Eds) (1996). Restoring the Productivity of West African Soils: Key to Sustainable Development. IFDC-Africa, Lomé -Togo / LEI. The Hague, The Netherlands. 
25. Morakinyo, A.T., Adeboye, O.B., Awogbuyi, O.T. (2013). Environmental effects of application of fertilizers and pesticides on water and soil in Ibadan, Nigeria. Journal of Emerging Trends in Engineering and Applied Sciences (JETEAS) 4(6): $773-777$ (jeteas.scholarlinkresearch.org).

26. Ouédraogo, S.R. (2002). Déterminants de l'adoption de la traction animale, des semences améliorées et des engrais chimiques dans les zones non cotonnières du Burkina Faso. Rapport de recherche, projet de court de terme. Fondation SADAOC et Université de Ouagadougou, Burkina Faso.

27. Ouédraogo, S. (2005). Les déterminants de la sécurité alimentaire dans le Plateau Central du Burkina Faso. Ph.D. Thesis, Centre for Development Studies, University of Groningen.

28. Sanchez P. A. and Jama B. A. (2002). Soil fertility replenishment takes off in East and Southern Africa. International Centre for Research in Agroforestry, Nairobi, Kenya. 352 p.

29. Sanders, J.H., Shapiro, B.I. \& Ramaswamy, S. (1996). The Economics of agricultural technology in Semi-Arid Sub-Saharan Africa. The Johns Hopkins University Press, Baltimore.

30. Semalulu, O., Mugonola, B., Bonabana-Wabbi, J., Kayangaand, S.T. \& Mogaka, H. (2014). Optimizing use of integrated soil fertility management options for profitable groundnut production in Uganda. Landmark Research Journal of Agriculture and Soil Sciences (LRJASS), 1(5)61-69.

31. Smaling, E.M.A. (1993). An agro-ecological framework for integrated nutrient management, with special reference to Kenya. Doctoral thesis, Wageningen Agricultural University, The Netherlands, $(X)+250$ pp.

32. Stewart, W.M. \& Roberts, T.L. (2012). Food security and the role of fertilizer in supporting it. $1^{\text {st }}$ International Symposium on Innovation and Technology in the Phosphate Industry [SYMPHOS 2011]. Procedia Engineering 46 (2012) $76-82$.

33. Stiglitz, J.E. (1986). The New Development Economics. World Development, 14, No. 2.

34. Suits, B.D. (1957). Use of dummy variables in regression equations. Journal of the American Statistical Association. Vol. 52, No. 280, p. 548 . 
35. Ton, P. \& Wankpo, E. (2004). La production du coton au Bénin. Projet No. 2618, Agriterra, Arnhem, Pays-Bas.

36. Tshibaka, B.T., Honfoga, B.G., Têvi, J., Houngbo, A. \& Dokoué, J. (1992). Facteurs déterminants de la connaissance, de l'adoption, de la diffusion et des effets des techniques culturales modernes et des engrais au Sud-Est du Togo. Rapport du 'Fertilizer Policy Research Project', IFRI/IFDC. Lomé, Togo.

37. Van Tilburg, A., Henk, A., Moll, J. \& Kuyvenhoven, A. (Eds.) (2000). Agricultural markets beyond liberalisation. Kluwers Academic Publishers, 101 Philip Drive, Assinippi Park, Norwell, Massachussets 02061.

38. Wallis, J. \& Dollery, B. (1999). Market failure, government failure, leadership and public policy. MacMillan Press Ltd, Great Britain.

39. Wanzala-Mlobela, M., Fuentes, P. \& Mkumbwa, S. (2013). Practices and Policy Options for the Improved Design and Implementation of Fertilizer Subsidy Programs in Sub-Saharan Africa. Final rapport. NEPAD \& IFDC, 163p.

40. Williams, M.S. (1958). Farmers' Decisions in the Use of Fertilizer. Journal of Farm Economics, Vol. 40, No. 5, Proceedings of the Joint Annual Meeting (Dec., 1958), pp. 1407-1415.

41. Zhou, Y., Yang, H., Mosler, H-J. \& Abbaspour, K.C. (2010). Factors affecting farmers' decisions on fertilizer use: A case study for the Chaobai watershed in Northern China. Consilience: The Journal of Sustainable Development Vol. 4, Issue 1 (2010), Pp. 80-102. 